\title{
Legal bid could extend US animal welfare law to cover lab rodents
}

[WASHINGTON] Lawyers for the US Department of Agriculture (USDA) have been given until tomorrow (16 July) to respond to a lawsuit filed in March by an animal rights group, the Alternatives Research and Development Foundation (ARDF).

The lawsuit, filed in US District Court in Washington, is the strongest challenge yet to the government's contention that some 23 million rats, mice and birds being used in research should not receive protection under the 1966 Animal Welfare Act.

If the USDA loses the lawsuit, the result would be annual, unannounced inspections at laboratories not now under the law's auspices, ranging from small liberal arts colleges whose animal use is confined to mice in psychology departments to labs at biotechnology start-up companies. Universities would be faced with a major increase in paperwork and other compliance requirements.

The lawsuit aims to require the department to extend the protection offered by the act. This explicitly covers dogs, cats, nonhuman primates, guinea pigs, hamsters and rabbits used in research. But it also applies to any "such other warmblooded animal as the Secretary [of Agriculture] may determine" is being used in research and other activities.

Arguing that this clause gives the USDA discretion on whether to include other animals, the department excluded birds, and rats and mice, whose numbers are exploding in research and which make up some 95 per

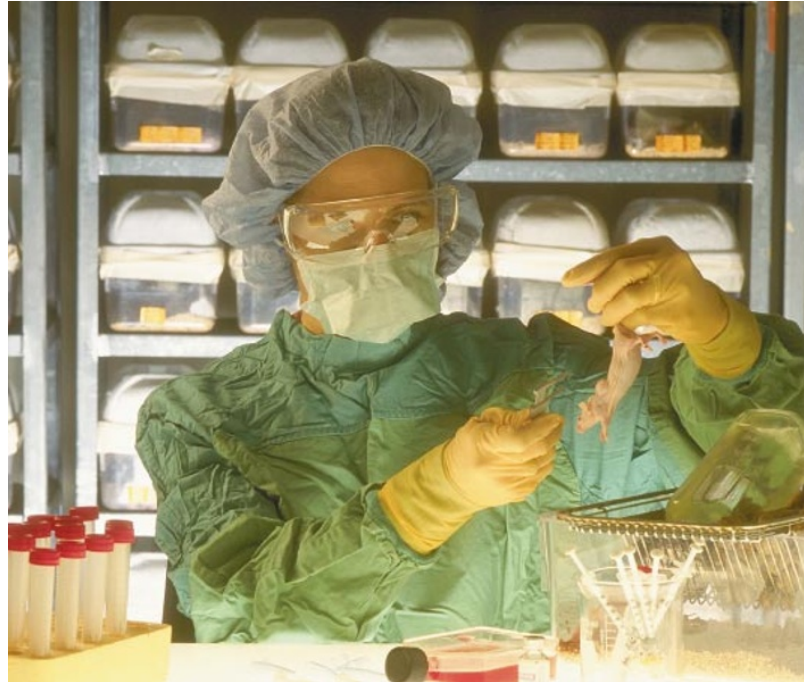

In safe hands? Universities and companies in the United States could face \$164 million in extra costs if campaigners succeed in extending to laboratory birds and rodents the legal protection already given to larger animals.

cent of US research animals. But animal rights activists contend that the law is meant to apply to all warm-blooded animals.

The government has been sued before to include rats, mice and birds under the act. In 1992, a federal judge agreed with the Humane Society of the United States and the Animal Legal Defense Fund that the animals should be covered. The judge called the USDA's argument "strained and unlikely". But two years later, an appeals court reversed the decision, saying the plaintiffs had not demonstrated that they had the legal standing to sue.

This time, says John McArdle, the ARDF director, the plaintiffs are optimistic that they

\section{spotlight on alternatives to using animals}

\section{[LONDON] The British} government is to carry out an audit of governmentfunded research into alternatives to the use of animals in research, before deciding whether to increase investment in this field.

George Howarth, the minister responsible for regulating the use of animals in research, made this pledge at a Home Office meeting last week with both supporters and opponents of the use of animals in research. The audit is expected to be completed by the end of the summer.

Howarth also promised to investigate ways of sharing data from research involving the use of animals - partly to avoid repeating the experiments. But he acknowledged that commercial organizations may be reluctant to do this.

The meeting, with representatives of more than 50 organizations, was the belated fulfilment of the Labour party's pre-election commitment to look into the use of animals in research. But Howarth remained noncommittal on another pledge: to set up a Royal Commission on the issue (see Nature 388, 311; 1997).

The meeting brought together representatives of government, scientists, patients' organizations, industry and animal rights groups. Some questioned the value of convening a large group involving many who are unlikely to change their views.

"Informal contacts can be more fruitful," commented one scientist. The problem, according to another, is that animal rights groups "do not accept the validity of any experiment that involves animals. You can't have dialogue in this situation."

The meeting was organized to explore common ground rather than to reach a consensus, says Howarth. Most agreed on the need to fund more alternatives.

Ehsan Masood have demonstrated legal standing, which requires showing direct harm to a plaintiff. McArdle says the ARDF, which is based in Eden Prairie, Minnesota, is harmed by the way the USDA has interpreted the law because the group's purpose is to develop and promote the use of non-animal research methods.

The issue is generating considerable heat. During a public comment period that closed in May, the USDA received almost 40,000 comments on a petition submitted last year by the ARDF and others asking it to add rats, mice and birds to the act's protection.

If the lawsuit prevails, paperwork and inspections would increase significantly at most major research universities, which are already covered by the law because of their use of other animals. At the University of Michigan, for example, the change would mean inspections of 51,000 rats and mice, in addition to the 6,000 animals currently examined in an annual five-day visit by the USDA.

Equally important to animal activists, however, is that researchers who use rats and mice would have to demonstrate that they have considered alternative ways of conducting their research. The law requires investigators to demonstrate that they have looked for alternatives, both to painful procedures and to the use of animals altogether. They also have to show that the work does not unnecessarily duplicate previous work. "A lab animal does not have to be the method of choice," says McArdle. "We want to require [researchers] under penalty of law" to consider alternatives.

Research advocacy groups, led by the National Association for Biomedical Research (NABR), argue that extending the law's coverage would cripple the branch of the USDA that is responsible for enforcing 
the law. With a $\$ 9.2$ million budget and 65 inspectors - down from 88 six years ago already covering 10,400 sites, the enforcers are stretched past breaking point, they say.

"Fundamentally we don't object to the addition of these species, but we don't want the whole programme compromised," says Barbara Rich, NABR's executive vicepresident. "I don't see how it wouldn't be."

But critics argue that the USDA's finances are not the issue. "Justice demands that we treat equal situations equally unless there is a morally significant difference between them," says Barbara Orlans, a senior research fellow at the Kennedy Institute for Ethics at Georgetown University in Washington, and one of the petitioners. McArdle says the USDA is "using a lack of money as a defence for not doing what they are legally required to do".

Based on a survey of its members, the NABR concluded that an extra $\$ 84$ million in administrative costs would be incurred at institutions already covered by the act. It estimates that, for companies and institutions not now covered, registration and compliance would cost at least $\$ 80$ million. The USDA estimated in 1990 that the number of research institutions it regulates would almost double if rats, mice and birds were covered.

The department declines to comment because the issue is under litigation. But the USDA has previously argued that such a change "would have serious consequences for the protection of other species" covered by the law because it would dilute enforcement efforts. It noted that Congress has never moved to include the rodents under the act, although it has amended it several times. "The vast majority of rats, mice and birds used in biomedical research are already afforded certain protections," it added.

This refers to the fact that researchers who receive Public Health Service funding agree to follow a policy on the humane use and care of laboratory animals that includes all vertebrates. But this policy does not require inspections, nor does it have the force of law.

Animal care administrators say that the requirements of excellent science, and the health service code, mean that rats, mice and birds are already treated as well as if they received protection under the act. "As far as the care of the animals [goes] it wouldn't make one whit of difference," says Daniel Ringler, director of the unit for laboratory animal medicine at the University of Michigan.

But a survey last month in Lab Animal turned up surprising results from members of Institutional Animal Care and Use Committees, the panels of veterinarians, researchers and other faculty members responsible for ensuring that their institutions comply with animal welfare rules. Of 491 committee members surveyed, 73 per cent said that rats and mice should be covered by the act. The same proportion was true for the 287 animal researchers in this group. Meredith Wadman

\section{Five young life scientists win \$1m no-strings grants}

[WASHINGTON] Five young US biologists have been chosen as the first recipients of $\$ 1$ million each by the W. M. Keck Foundation. They can use this money to pursue exciting ideas as they see fit, free of the restrictions that usually accompany research grants.

Bruce Clurman of the Fred Hutchinson Research Center in Seattle, Judith Frydman of Stanford University, Partho Ghosh of the University of California at San Diego, Phyllis Hanson of Washington University, St Louis, and Mark Gerstein of Yale University were informed last week that they are to receive the first five awards in Keck's programme. There were 24 nominations by various biomedical research centres.

Frydman, a 35-year-old who will use her award to investigate protein folding, says that it will offer far more flexibility than a grant from the US National Institutes of Health, for which an outline of the proposed work has to be planned in advance. "This will allow me to start asking new questions, where I'm not necessarily sure what is going to be the right approach," she says.

Ghosh, a 36-year-old structural biologist, says his award will support "a lot of projects that a young professor might otherwise have difficulty taking on". He added that his laboratory will investigate proteins that are developed by pathogens to breach the membranes protecting host cells.

The foundation launched the programme last year, after deciding that young biomedical researchers at the peak of their creativity were being hemmed in by the strings attached to conventional grants. It intends to select five more young professors for each of the next four years, spending \$25 million in all. The awards are open to US citizens who have held faculty positions for no more than three years and who are investigating "fundamental mechanisms of human disease".

According to William Butler, chancellor of Baylor College of Medicine in Houston, Texas, and chair of the advisory panel for the programme, they are also intended to address what he terms the "incredible funding pressures" at US medical schools caused by sharp reductions in hospital bed income.

The W. M. Keck Foundation was set up 45 years ago by the founder of the Superior Oil Company, and is now one of the largest philanthropic organizations in the United States, with $\$ 1.5$ billion of assets.

colin Macilwain

\section{UK biotech industry aims to clean up its act}

[LONDON] The leaders of Britain's

biotechnology industry have decided to get tough with companies that bring the industry into disrepute, issuing a draft code of practice for companies in the medical and life sciences sector.

The code is aimed at managing the flow of scientific information to shareholders in a way that does not adversely affect a company's share price, nor falsely raise expectations from patients' groups.

The nine-point code, released for public comment last week by the BioIndustry Association (BIA), is also aimed at helping bioscience companies to avoid the fate of the deeply troubled, but one-time flagship company, British Biotech.

The company was censured last month by the London Stock Exchange and the US Securities and Exchange Commission after an investigation concluded that it had issued misleading assessments on the status of its drugs trials (see Nature 392, 852; 1998).

While the code is not mandatory, all of the BIA's member companies listed on the Stock Exchange will be asked to provide information on the state of compliance in their annual reports. Companies will have to provide reasons for non-compliance. The identity of those who refuse to comply will be made public. Some could even be expelled.

The code has been enthusiastically received by many companies in Britain's 460 -strong bioscience sector, as well as by the Stock Exchange and the Association of British Insurers, which represents the single largest shareholding community.

"The financial community expects company information to be full, frank and open. That's what the code hopes to achieve," says BIA chief executive John Sime.

"Investors tell us they will take a dim view of companies who do not comply," says Robert Mansfield, BIA's chairman. "In the life sciences, there has to be a partnership between management and shareholders. It is a long-term relationship based on trust."

The code's provisions include: ensuring that the boards of companies have access to independent scientific advice, and expertise in handling scientific information; making sure that information to investors is as transparent and accurate as possible, and avoiding any temptation to oversell the implications of a result. The code also asks company scientists to exercise caution when discussing potentially price-sensitive information with peers.
Ehsan Masood 